\title{
Wielowariantowa predykcja prędkości fali S w ocenie parametrów sprężystych formacji łupkowych
}

\section{Multivariate S-wave velocity prediction in the assessment of elastic parameters in shale formations}

\author{
Weronika Kaczmarczyk, Małgorzata Słota-Valim
}

Instytut Nafty i Gazu - Państwowy Instytut Badawczy

\begin{abstract}
STRESZCZENIE: Rozpoznanie i udostępnianie złóż niekonwencjonalnych stanowi ogromne wyzwanie. Złoża te ze względu na swoją nietypowość, objawiającą się ograniczonymi właściwościami filtracyjnymi, wymagają indywidualnego podejścia i wykorzystania specyficznych rozwiązań. Obejmują one między innymi wyznaczanie stref o wyższym potencjale węglowodorowym, tzw. sweet spotów, dowiercanie się do złoża przy wykorzystaniu technologii wiercenia poziomego czy planowanie, jak też przeprowadzanie zabiegów stymulacji skał na drodze szczelinowania hydraulicznego. Analiza odpowiedniej kombinacji parametrów w tym przypadku może okazać się kluczowa i dostarczać niezwykle istotnych informacji o złożu. Parametry sprężyste, jako jedne z istotniejszych parametrów pozwalających scharakteryzować złoże, np. pod kątem podatności skał na szczelinowanie, wymagają między innymi dostępności informacji o przebiegu fali poprzecznej $V s$, która w przeciwieństwie do danych dotyczących prędkości fali podłużnej $V p$, jest rzadko mierzona w standardzie krajowym. W związku z tym w niniejszym artykule omówiono wielowariantową predykcję prędkości fali poprzecznej przy wykorzystaniu znanych z literatury i zmodyfikowanych modeli teoretycznych, w tym modelu Castagny oraz Greenberga i Castagny. Wykorzystując otrzymane wyniki, obliczono parametry sprężyste, na których podstawie w kolejnym etapie możliwa była interdyscyplinarna charakterystyka formacji złożowej, np. w aspekcie oceny podatności formacji złożowej na szczelinowanie hydrauliczne i powstanie tym samym szczelin technologicznych stanowiących ścieżkę migracji dla płynów złożowych. Bazując na różnych rozwiązaniach, opracowano w skali otworów wiertniczych 5 wariantów prędkości fali poprzecznej, której wyniki następnie posłużyły do obliczenia modułów sprężystych: modułu Younga i współczynnika Poissona. Ponieważ analizowany obszar badań charakteryzował się dostępnością danych o prędkości fali poprzecznej we wszystkich 4 analizowanych otworach, możliwa była weryfikacja wyników estymowanych parametrów. W dalszej kolejności do przestrzennej charakterystyki złoża zastosowano warianty obliczeń modułu Younga, wykorzystując w procesie integracji dane sejsmiczne. Analizę prowadzono w ordowicko-sylurskich formacjach łupkowych zdeponowanych w basenie bałtyckim, w interwałach wzbogaconych w materię organiczną.
\end{abstract}

Słowa kluczowe: fala poprzeczna, formacje łupkowe, basen bałtycki, parametry sprężyste.

ABSTRACT: Exploration and development of the hydrocarbons reservoir in unconventional rock formation is a huge challenge. Due to their specific nature, which is manifested by limited filtration properties, they require an appropriate approach and the use of specific solutions. They include, among others, the determination of zones with higher hydrocarbon potential - so called sweet spots, application of horizontal drilling technology, or designing as well as performing rock stimulation treatments of rocks usually with low or almost zero permeability with the use of hydraulic fracturing. The analysis of the right combination of parameters in this case can be essential and provide extremely important information about the reservoir in an unconventional rock formation. As one of the most important parameters allowing, among others, to characterize the reservoir in terms of rock susceptibility to hydraulic fracturing, elastic properties require the availability of shear wave $V s$, which in contrast to compressional wave $V p$ in the Polish standard is measured rarely. Therefore, in this paper, a multivariate prediction of shear wave velocity was developed with the use of theoretical models known from the literature and modified, based on which we estimate the elastic parameters. Using the obtained results, the elastic parameters were calculated on the basis of which, in the next stage, interdisciplinary characterization of reservoir formation is possible, e.g. in the aspect of assessing the reservoir formation susceptibility to hydraulic fracturing and thus creating technological fractures constituting the migration path for reservoir fluids. Based on different solutions, 5 variants of shear wave velocity were developed in the borehole scale, the results of which were then used to calculate the elastic modules: the Young modulus and the Poisson ratio. Because of the availability of the measured shear wave in each analyzed wellbores, it was possible to verify the results of the estimated variants. Subsequently, for the purpose of spatial characterization of the reservoir, calculated variants of the Young modulus were integrated with the seismic data. The analysis was conducted in Ordovician - Silurian shale formations in the Baltic Basin, at intervals enriched with organic matter.

Key words: shear wave, shale formations, Baltic basin, elastic properties.

Autor do korespondencji: W. Kaczmarczyk, e-mail: weronika.kaczmarczyk@inig.pl

Artykuł nadesłano do Redakcji: 04.12.2019 r. Zatwierdzono do druku: 29.06.2020 r. 


\section{Wprowadzenie}

Kompleksowa charakterystyka złoża wymaga dostępności szerokiego wachlarza różnego rodzaju danych, które ogólnie można podzielić na otworowe i sejsmiczne. Analiza odpowiedniej kombinacji parametrów może dostarczyć niezwykle ważnych informacji o złożu. Parametry sprężyste, jako jedne $\mathrm{z}$ istotniejszych parametrów, pozwalających m.in. scharakteryzować złoże pod kątem podatności skał na szczelinowanie, wymagają dostępności prędkości fali poprzecznej $V s$, która rzadko jest mierzona w przeciwieństwie do prędkości fali podłużnej $V p$. W niniejszym artykule omówiono wielowariantową predykcję prędkości fali poprzecznej, na podstawie czego następnie możliwa była estymacja parametrów sprężystych, a na ich podstawie interdyscyplinarna charakterystyka złoża, która dotyczy m.in. oddzielności litostratygraficznej, identyfikacji tzw. sweet spotów, podatności na szczelinowanie, charakterystyki naprężeń i relacji między poszczególnymi cechami złoża.

Analizę prowadzono w obszarze cechującym się dostępnością estymowanych parametrów, dzięki czemu możliwa była ich weryfikacja. Wyniki zaprezentowane w postaci przebiegu zmienności poszczególnych wariantów parametrów sprężystych - współczynnika Poissona i modułu Younga - pokazują analogiczne trendy zmienności w analizowanym otworze wiertniczym. Pozwala to na wysnucie wniosku, że przynajmniej w ocenie jakościowej, np. podatności skały na szczelinowanie na podstawie zmienności parametrów sprężystych, nie ma potrzeby pomiaru fali poprzecznej, gdyż wyniki oparte na modelach teoretycznych dają niemalże identyczne rezultaty. Finalne wyniki przedstawiono w postaci map średnich wartości modułu Younga w interwale analizowanych poziomów macierzystych.

\section{Obszar analizy}

Obszar badań zlokalizowany jest w obrębie basenu bałtyckiego, który ukształtowany został na zachodnim skraju kratonu wschodnioeuropejskiego EEC (ang. East European Craton). Podobnie jak basen podlasko-lubelski - w ostatnich latach był on przedmiotem intensywnych poszukiwań węglowodorów w formacjach łupkowych w Polsce. Skałą macierzystą i zarazem złożową są tu ilasto-mułowcowe łupki górnego ordowiku i/lub syluru wykazujące wzbogacenie w materię organiczną sięgające lokalnie do 12\% TOC (Poprawa i Kiersnowski, 2008; Poprawa, 2009, 2010; Kwietniak et al., 2018). Analizy laboratoryjne wykazały, że w omawianych formacjach występuje ropa nienasycona gazem, co z uwagi na większą lepkość medium złożowego utrudnia jego przepływ w ośrodku skalnym. Niniejszy artykuł ma za zadanie przedstawić uniwersalne, przeznaczone do wszystkich typów litologicznych złóż możliwości estymacji fali poprzecznej, która może posłużyć np. do oceny podatności na szczelinowanie ośrodka geologicznego. Podatność skały na szczelinowanie charakteryzowana jest m.in. poprzez wskaźnik kruchości skały, której skład mineralny obejmuje minerały o większej kruchości (kwarc, dolomit) lub/i mniejszej (minerały ilaste). Udział tych grup minerałów stanowi o większej lub mniejszej podatności skały na przeprowadzenie zabiegu szczelinowania hydraulicznego. Wybór miejsca wiercenia oraz optymalnej trajektorii poziomego odcinka, na którym planowany jest zabieg szczelinowania skały, a także geometria wtórnych szczelin uwarunkowane są rozkładem naprężeń oddziałujących w poddanym stymulacji ośrodku skalnym (Słota-Valim, 2014). Z kolei to, czy i w jakim stopniu skała podda się zeszczelinowaniu, zależy od doboru parametrów zabiegu stymulacji, ale głównie od geomechanicznych własności ośrodka, które mogą być wyrażone przez parametry sprężyste, w tym moduł Younga, współczynnik Poissona, stałe Lamégo, oraz parametry wytrzymałościowe, jak wytrzymałość na ściskanie, rozciąganie czy kąt tarcia wewnętrznego (Jędrzejowska-Tyczkowska i Słota-Valim, 2012; Kasza et al., 2016). Analiza prowadzona była w dwóch interwałach charakteryzujących się zwiększoną zawartością materii organicznej, nazwanych poziomem macierzystym I (PM_I) i poziomem macierzystym II (PM_II).

\section{Parametry sprężyste}

Jednym ze sposobów wyrażenia podatności skał na szczelinowanie jest wykorzystanie parametrów sprężystych, w tym współczynnika Poissona (v) i modułu Younga $(E)$. Moduł Younga $(E)$ to wielkość określająca sprężystość materiału, wyrażająca charakterystyczną dla danego materiału zależność względnego odkształcenia liniowego $\varepsilon$ od naprężenia $\sigma$, jakie występuje w tym materiale w zakresie odkształceń sprężystych (Slatt, 2011; Varacchi et al., 2012) (1):

$$
E=\sigma / \varepsilon
$$

Moduł Younga, inaczej sztywność skały, określa zdolność skały do deformacji. Skały o wysokim module Younga, tj. bardziej sztywne, są mniej podatne na odkształcenia plastyczne, co na krzywej przedstawionej na rysunku 1 objawia się bardziej stromym przebiegiem krzywej naprężenie-odkształcenie. Współczynnik Poissona (v) natomiast to wielkość wyrażająca stosunek względnego odkształcenia poprzecznego do względnego odkształcenia w kierunku działania naprężenia (wyrażonych w jednostce długości). Współczynnik Poissona próbki skalnej poddanej obciążeniu wzdłuż jednej osi może być opisany wzorem (Bjørlykke et al., 2010; Zoback, 2010; Slatt, 2011) (2): 


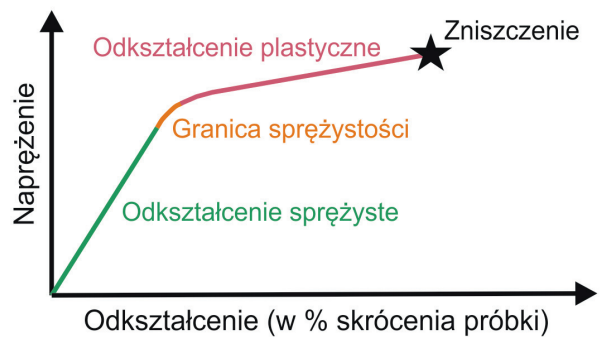

Rys. 1. Zależność naprężenia od odkształcenia. Na rejestrowanej krzywej można wyróżnić strefę odkształceń sprężystych do punktu granicznego wyznaczającego początek strefy nieodwracalnych odkształceń plastycznych, kończących się zniszczeniem materiału

Fig. 1. Dependence of stress on deformation. On the recorded curve, one can distinguish the elastic deformation zone to the border point marking the beginning of the irreversible plastic deformation zone, which ends with the destruction of the material

$$
v=-\varepsilon_{1} / \varepsilon_{a}
$$

gdzie:

$\varepsilon_{1}$ - odkształcenie poprzeczne [m],

$\varepsilon_{a}$ - odkształcenie osiowe [m].

Wartości statycznych modułów sprężystości wyznaczane są w testach ściskania jedno- lub trójosiowego przeprowadzanych na wyciętych ze skały próbkach. Dynamiczne moduły sprężystości można natomiast obliczyć na podstawie prędkości fal sprężystych: fali podłużnej $(V p)$ i poprzecznej $(V s)$ oraz gęstości skały $(\rho)$ według zależności (Bratton i Cooper, 2009; Herwanger i Koutsabeloulis, 2011; Słota-Valim, 2015) (3), (4):

$$
\begin{gathered}
v d y n=V p^{2}-V s^{2} / 2\left(V p^{2}-V s^{2}\right) \\
E d y n=\rho V s^{2}\left[\left(3 V p^{2}-4 V s^{2}\right) /\left(V p^{2}-V s^{2}\right)\right]
\end{gathered}
$$

gdzie:

$v d y n$ - dynamiczny współczynnik Poissona (wielkość bez-

wymiarowa),

Edyn - dynamiczny moduł Younga [Pa],

$V p$ - prędkość fali podłużnej,

$V s$ - prędkość fali poprzecznej $[\mathrm{m} / \mathrm{s}]$,

$\rho-$ gęstość objętościowa $\left[\mathrm{g} / \mathrm{cm}^{3}\right]$.

Moduł Younga i współczynnik Poissona to podstawowe parametry sprężyste, za pomocą których możliwa jest jakościowa ocena podatności skał na szczelinowanie hydrauliczne. Skały bardziej kruche będą się charakteryzować wyższymi wartościami modułu Younga i niższymi wartościami współczynnika Poissona (Cyz et al., 2018).

\section{Wielowariantowa estymacja fali poprzecznej}

Fala poprzeczna $\mathrm{S}$ to fala sprężysta, która propagując, powoduje ruch cząsteczek ośrodka, przez który przechodzi, w kierunku prostopadłym do kierunku propagacji. Cechą charakterystyczną fali poprzecznej S jest to, że nie propaguje w płynach. Prędkość fali S zależy od sprężystości i gęstości ośrodka, w którym się rozchodzi, i może być wyrażona wzorem:

$$
V s=\sqrt{\mu / \rho}
$$

gdzie $\mu$ to moduł ścinania, a $\rho$ to gęstość ośrodka, w którym propaguje fala poprzeczna. Prędkości fali S w formacjach łupkowych według Castagny i in. (1985) mieszczą się w zakresie $1100-2300$ m/s i nie wykazują zróżnicowania w zależności od nasycenia ośrodka płynem. Znajomość prędkości fal sprężystych P i S pozwala na wyznaczanie parametrów sprężystych ośrodka skalnego, w tym współczynnika Poissona (3) i modułu Younga (4).

Na potrzeby obliczeń parametrów sprężystych wymagana jest informacja dotycząca prędkości fali poprzecznej, która zazwyczaj nie jest mierzona w otworach. W ramach niniejszego artykułu zestawiono kilka wariantów szacowania tego parametru:

Wariant I - pomiar w otworze, średnia wartość w obrębie analizowanych formacji o wysokiej zawartości TOC dla $V p$ wynosi $3723,33 \mathrm{~m} / \mathrm{s}$, a dla $V s$ 2130,58 m/s, a współczynnik korelacji pomiędzy prędkościami obu tych fali jest na poziomie 0,7385 . Wariant II - funkcja liniowa opisująca zależność pomiędzy prędkością fali podłużnej i poprzecznej wyznaczona w jednym z otworów:

$$
V s_{\text {II }}=0,575 \cdot V p-113,4565
$$

Wariant III - model estymacji prędkości fali poprzecznej zaproponowany w 1985 roku dla mułowców (Castagna et al., 1985):

$$
V S_{-} \mathrm{III}=\frac{V p-1360}{1,16}
$$

Wariant III' - model estymacji prędkości fali poprzecznej zaproponowany w 1992 roku dla łupków (Greenberg i Castagna, 1992):

$$
V S_{-}{ }_{\text {III' }}=0,7697 V p-0,86735
$$

Wariant III" - estymacja prędkości fali poprzecznej w wariancie III' z uwzględnieniem oszacowanego współczynnika dopasowania a_INIG.

$$
V s_{-}{ }_{\text {III" }}=V s_{-I I I} \cdot a_{-I N I G}
$$

Wyniki poszczególnych wariantów w postaci krzywych zostały zestawione ze sobą i poddane analizie porównawczej. We wszystkich otworach w zasięgu analizowanych interwałów (PM_I i PM_II) pomimo zastosowania odmiennych podejść estymacyjnych przebieg poszczególnych krzywych jest istotnie zbliżony. Jedynie zakres wartości wyniku bazującego na literaturowym modelu Castagny jest nieco przesunięty, 


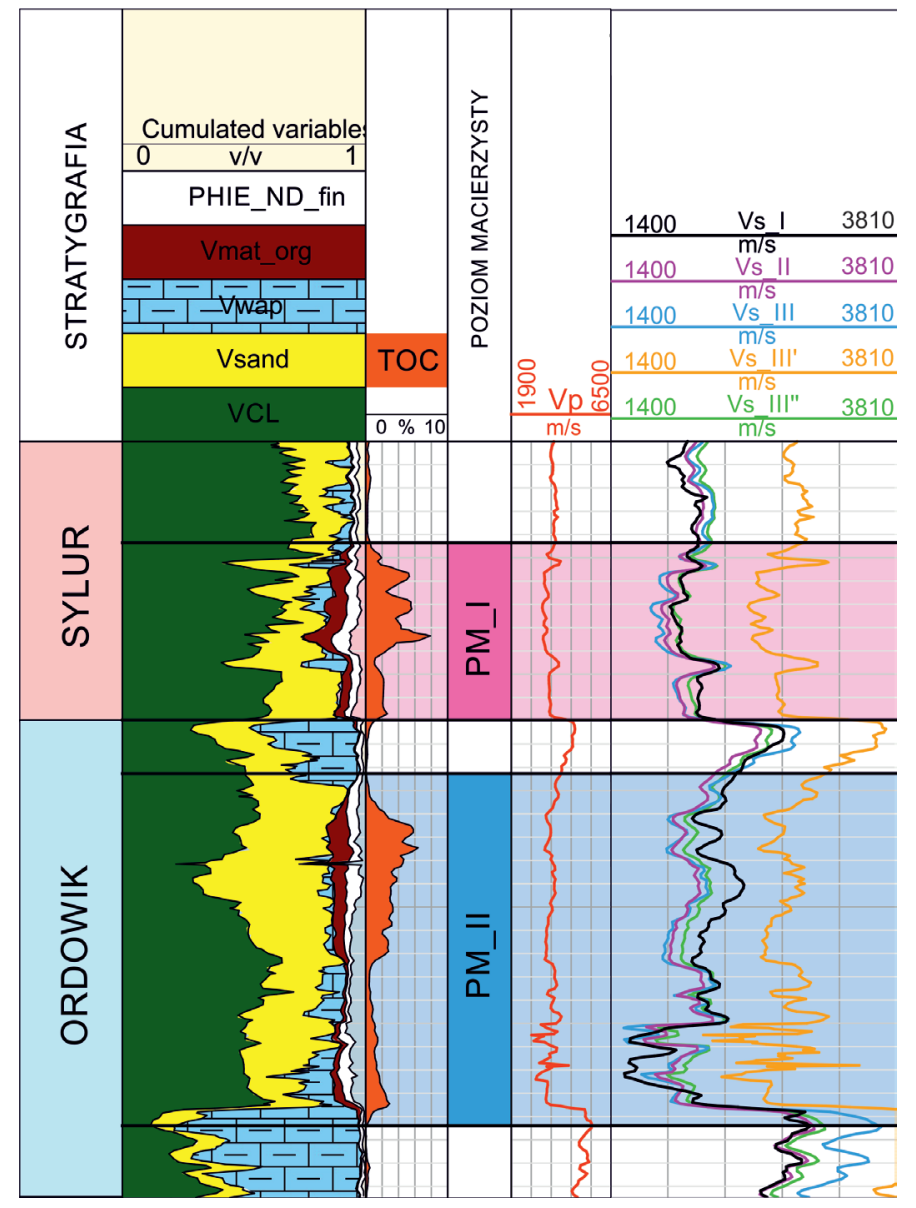

Rys. 2. Zestawienie otworowych danych wejściowych (ścieżka 1 podział stratygraficzny, 2 - rozwiązanie litologiczne, 3 - zawartość TOC [\%], 4 - podział na strefy macierzyste, 5 - prędkość fali $V p$, 6 - wyniki estymacji poszczególnych wariantów prędkości fali S)

Fig. 2. Summary of well input data (track no. 1 - stratigraphy division, track no. 2 - lithological model, track no. 3 - TOC content [\%], track no. 4 - source intervals, track no. $5-V p$ velocity, track no. 6 - variants of $V s$ velocity estimation)

jednak z zachowaniem rozpiętości wartości tych zakresów, w związku z czym oszacowano wartość współczynnika ( $\mathrm{a}_{\text {_NIG }}$ ), którego zastosowanie w iloczynie do podstawowego modelu Castagny (wariant III) dobrze przybliża pomierzone prędkości fali poprzecznej w poszczególnych otworach. Współczynnik ten został arbitralnie dobrany tak, aby możliwie jak najwierniej odzwierciedlał przebieg pomierzonej fali $V s \mathrm{w}$ całym analizowanym interwale. Na rysunku 2 przedstawiono wyniki dla wszystkich wariantów estymacji prędkości fali poprzecznej dla jednego $\mathrm{z}$ analizowanych otworów.

\section{Walidacja uzyskanych wyników}

Przedstawienie na rysunku 2 wyników poszczególnych wariantów estymacji prędkości fali poprzecznej pozwala na jakościową ocenę dopasowania do pomiaru rzeczywistego tego parametru. Na tej podstawie można stwierdzić, że krzywa $V s_{-}$ najsłabiej odzwierciedla krzywą referencyjną $V S_{\_}$. W celu jakościowej oceny uzyskanych wyników przeprowadzono walidację rezultatów estymacji prędkości fali poprzecznej w odniesieniu do rzeczywistego pomiaru tego parametru w jednym $\mathrm{z}$ analizowanych otworów. Analizie poddano wszystkie warianty estymowanego parametru oparte na różnych modelach teoretycznych, na podstawie czego możliwe było ilościowe wytypowanie optymalnego wariantu do dalszych rozważań. Obliczono różnicę pomiędzy profilem rzeczywistym i estymowanym (R), jak również pierwiastek błędu średniokwadratowego (RMSE - ang. root-mean-square error). Wyniki przedstawiono na rysunku 3 oraz w tabeli 1 .

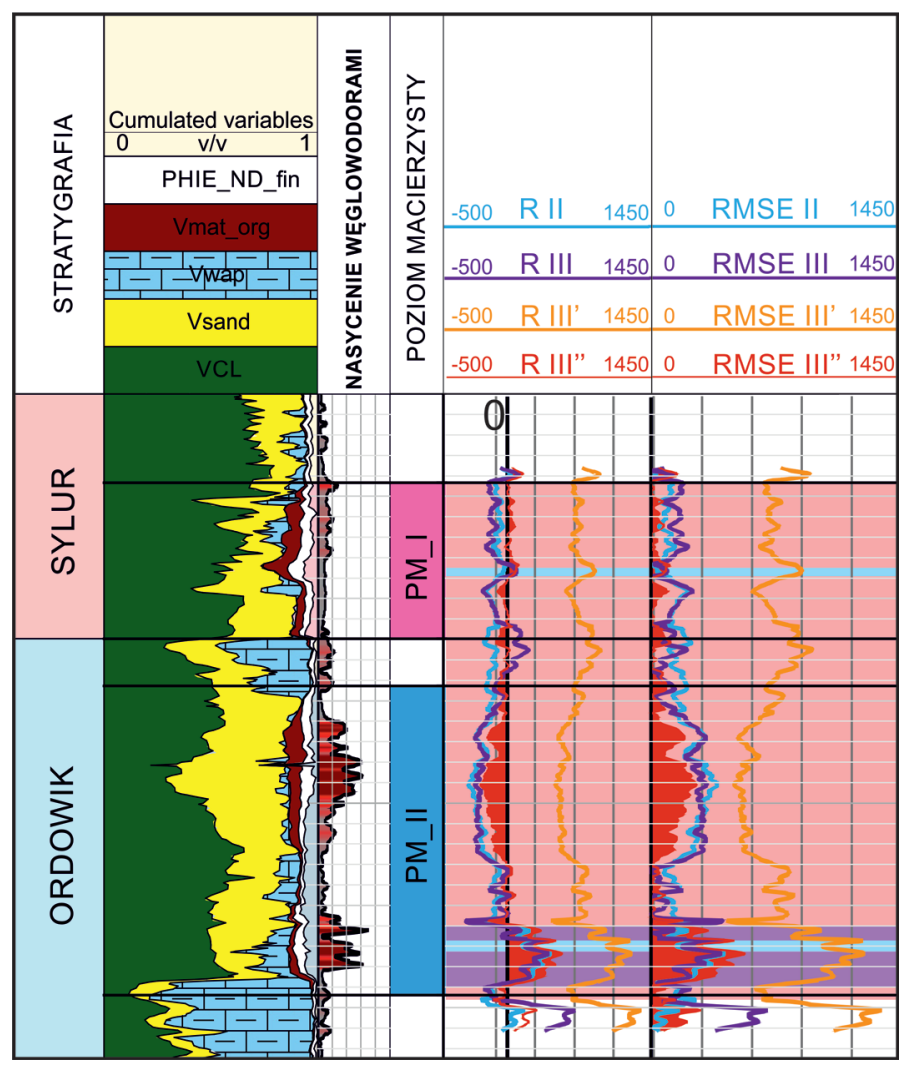

Rys. 3. Graficzna prezentacja wyników przeprowadzonej walidacji parametru prędkości fali poprzecznej dla jednego z otworów na analizowanym obszarze. Parametr $\mathrm{R}$ to różnica między profilem rzeczywistym a estymowanym (R II, III, III', III" = $V S_{\_}-$ $V S$ _II, _III, _III', _III"), RMSE - pierwiastek błędu średniokwadratowego RMSE $=\sqrt[2]{\left(V s_{-I}-V s_{-I I}, \text { III -III,-III" }\right)^{2}}$

Fig. 3. Results of shear wave velocity estimation for one of the analyzed wells. The $\mathrm{R}$ parameter is defined as a difference between the estimated and the validated curve, the RMSE parameter refers to the root-mean-square error RMSE $=\sqrt[2]{\left(V s_{-I}-V s_{-I I},- \text { III -III,-III" }\right)^{2}}$

Istota prezentowanej procedury walidacyjnej polega na porównaniu danych rzeczywistych z wynikami zastosowanej metody celem wzajemnej konfrontacji i weryfikacji metod geostatystycznych (Sowiżdżał, 2013). W profilu otworu z rysunku 2 prędkość fali poprzecznej ma następującą charakterystykę: wartość minimalna: 1503,84 m/s, wartość maksymalna: 3094,03 m/s, wartość średnia: 2228,02 m/s, odchylenie 
standardowe: $318,39 \mathrm{~m} / \mathrm{s}-\mathrm{w}$ interwale od stropu PM_I do spągu PM_II. Pożądany, najmniejszy błąd średniokwadratowy spośród wszystkich czterech wariantów estymacji odnosi się do krzywej prędkości obliczonej dla wa-

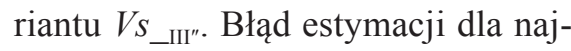
lepiej dopasowanego wariantu krzywej $V S_{-I I "}$ do referencyjnej $V S_{\_}$I wynosi 42,94 i 160,9 - odpowiednio dla poziomu PM_I i PM_II. Różnice (R) zaprezentowane na rysunku $3 \mathrm{w}$ postaci krzywych pokazują niedoszacowane (wartości ujemne) oraz przeszacowane (wartości dodatnie) wartości analizowanego parametru. Przedstawione w tabeli wartości NormRMSE odnoszą się natomiast do znormalizowanego błędu średniokwadratowego wyrażonego w procentach. Różnice w odchyleniu estymowanych krzywych wynikają z obecności węglowodorów w otwartej przestrzeni porowej, rejestrowanych przez pomiar fali podłużnej, na podstawie którego estymowane były poszczególne warianty prędkości fali poprzecznej.

\section{Kalkulacja modułu Younga i wspótczynnika Poissona}

W kolejnym kroku wyniki poszczególnych wariantów estymacji prędkości fali poprzecznej__, _II, _III, _III" wykorzystano do obliczeń wspomnianych wcześniej dwóch istotnych parametrów sprężystych: modułu Younga $(E)$ i współczynnika Poissona ( $v$ ) według wzorów (3) i (4), podstawowych parametrów geomechanicznych, na podstawie których możliwa jest np. analiza podatności ośrodka skalnego na szczelinowanie hydrauliczne.

Dla obliczonych wariantów współczynnika Poissona (PR) obserwuje się ewidentny trend spadku wartości w strefach wzbogaconych w minerały węglanowe oraz nieco mniej wyraźny w strefach z dużym udziałem kwarcu. Natomiast w strefach wzbogaconych w substancję organiczną i/lub minerały ilaste występuje wzrost wartości tego współczynnika.

Współczynniki Poissona_II i _III (obliczone z wykorzystaniem prędkości fali poprzecznej odpowiednio w wariancie_II i_III) charakteryzują się niemal identycznym przebiegiem. Od wyznaczonego przez PR_I trendu odbiegają w przystropowej części poziomu macierzystego II, w strefie wzbogaconej w kwarc, w której PR_I charakteryzuje się najbardziej wyraźnym spadkiem wartości, oraz w strefach ze zwiększonym udziałem minerałów węglanowych, tj. w strefie granicznej między analizowanym poziomem macierzystym I i II oraz w przyspągowej części poziomu macierzystego II. Z uwagi na znaczącą różnicę wartości współczynnika Poissona, jaką

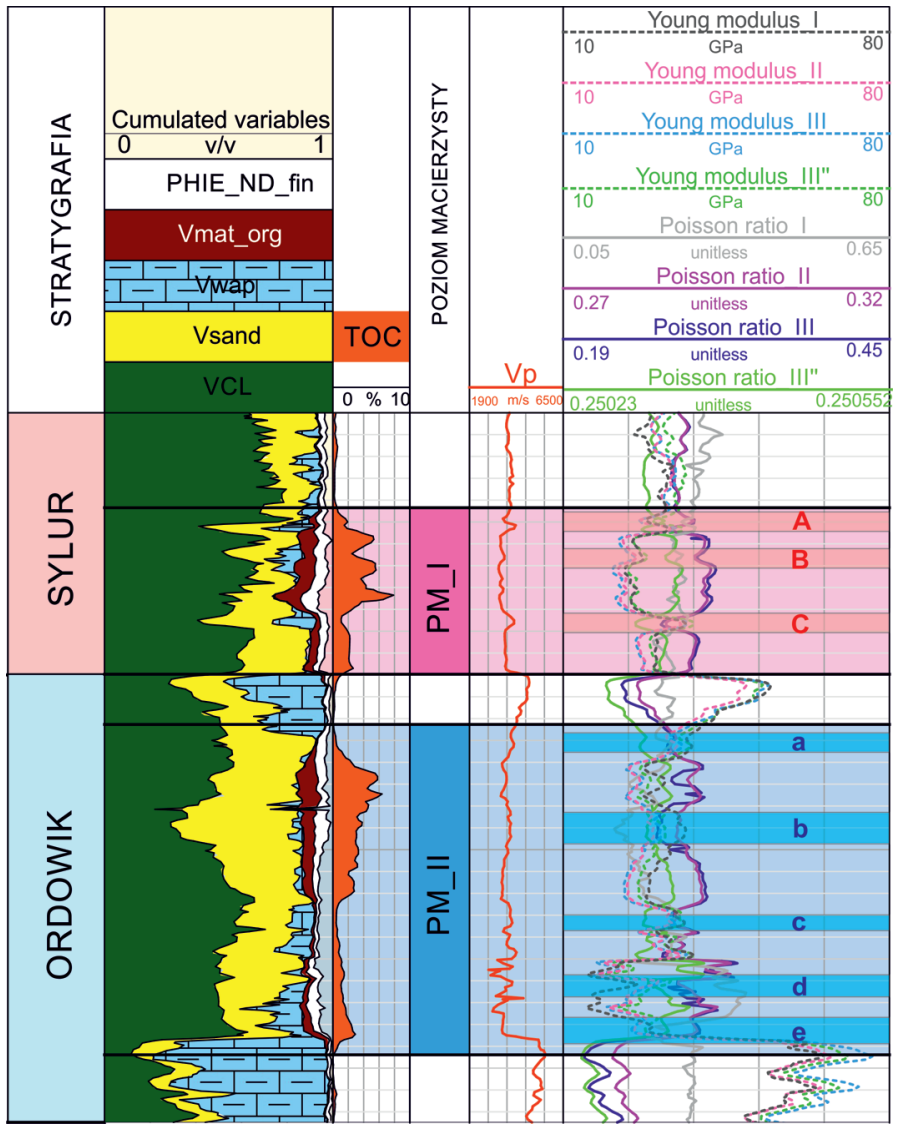

Rys. 4. Wyniki przebiegu poszczególnych wariantów modułu Younga i współczynnika Poissona zestawione z danymi wejściowymi, ścieżki: 1 - stratygrafia, 2 - model mineralogiczny, 3 - zawartość TOC, 4 - prędkość fali $V p, 5$ - obliczone moduły sprężystości (moduł Younga oraz współczynnik Poissona w wariantach I, II, III i III")

Fig. 4. Results of elastic parameters (Young modulus and Poisson ratio) estimation variants together with appropriate input data: track no. 1 stratigraphy division, track no. 2 - mineralogical model, track no. 3 - TOC content, track no. 4 - source intervals, track no. 5 - compressional wave velocity $V p$, track no. 6 - calculated variants of Young modulus and Poisson ratio 
przyjmuje się dla minerałów węglanowych, tj. 0,30 dla kalcytu i 0,15 dla dolomitu, cenne również wydawałoby się rozdzielenie węglanów na poszczególne minerały węglanowe, a następnie sprawdzenie, jak zachowują się obliczone wartości współczynnika Poissona względem ich objętości. Z kolei przebieg wartości modułów Younga charakteryzuje się trendami odwrotnymi, tj. wzrost wartości modułów Younga obserwuje się w strefach o zwiększonym udziale kwarcu i minerałów węglanowych, przy czym efekt ten jest najbardziej wyraźny w przypadku tych drugich. Natomiast wartości obliczonych modułów spadają przy rosnącym udziale minerałów ilastych i materii organicznej. Należy zaznaczyć, że trend zmiany wartości wszystkich wariantów modułów Younga jest bardzo zbliżony, a obliczone wartości porównywalne, jednocześnie czułe na zmiany zawartości kwarcu i minerałów węglanowych.

\section{Ocena podatności na szczelinowanie na podstawie estymowanych parametrów sprężystych}

Na podstawie zmian trendu wartości obliczonych wariantów dynamicznych parametrów sprężystych - współczynnika Poissona i modułu Younga, dyktowane w dużej mierze przez zawartości kruchych minerałów takich jak kwarc i dolomit, możliwa jest jakościowa ocena podatności na szczelinowanie hydrauliczne analizowanych formacji łupkowych (Bała, 2017a, 2017b; Cyz et al., 2018). Skały podatne na powstanie technologicznych szczelin będą charakteryzować się podwyższonymi wartościami modułu Younga i niskimi wartościami współczynnika Poissona.

Na rysunku 4, na ścieżce 6, gdzie zestawione są krzywe współczynników Poissona i modułów Younga we wszystkich wariantach, zaznaczono 8 interwałów charakteryzujących się większą podatnością na szczelinowanie. W poziomie macierzystym PM_I stwierdza się występowanie trzech stref bardziej podatnych na szczelinowanie. Pierwsza z nich, strefa A, zlokalizowana jest w części przystropowej formacji łupków sylurskich i charakteryzuje się wzbogaceniem w kwarc i minerały węglanowe na poziomie odpowiednio $33 \%$ oraz $18 \%$ objętościowych. Z punktu widzenia uzyskania jak najwyższej produkcji węglowodorów szczególnie interesująca jest strefa B, występująca bliżej środka w profilu analizowanego interwału PM_I. Jest to strefa, która oprócz nieco wyższej podatności na szczelinowanie cechuje się wysokim wzbogaceniem w materię organiczną. Udziały procentowe kwarcu, minerałów węglanowych i TOC dla omawianej B strefy wynoszą kolejno: 18,5\%, 11\% i 4,9\% objętościowych. Trzecia w profilu łupków sylurskich strefa $(\mathrm{C})$ posiada udziały minerałów kruchych porównywalne z pierwszą strefą (A), a mianowicie kwarc stanowi około 32\% objętości skały, a minerały węglanowe około $20 \%$. Podobnie jak w przypadku interwału sylurskiego obliczone parametry sprężyste pomocne były we wskazaniu stref o podniesionej podatności w łupkach ordowiku (PM_II). W poziomie macierzystym II stwierdzono występowanie pięciu stref o podwyższonej podatności na szczelinowanie. Pierwsza z nich, strefa a, zlokalizowana jest w części przystropowej profilu łupków ordowickich i swoją wysoką podatność zawdzięcza dość wysokim udziałem węglanów w swej górnej części (27\%) i kwarcu w części dolnej (45\%). Druga strefa (strefa b) o podwyższonej podatności charakteryzuje się najwyższymi w analizowanych interwałach PM_I i PM_II udziałami kwarcu, który stanowi nawet 53\% objętości skały. Minerały węglanowe występują tu w mniejszych ilościach i stanowią tylko 2,5\% do 3\% objętościowych. Omawiana strefa przy swojej podatności na szczelinowanie jest bardzo zasobna w materię organiczną, stanowiącą aż 6\% objętościowych. Jest to najbardziej perspektywiczna strefa w analizowanym poziomie macierzystym. W kolejnej, trzeciej strefie (strefa c) analizowanego profilu formacji łupków ordowiku wysoka podatność jest związana ze stosunkowo wysokimi udziałami kwarcu i minerałów węglanowych - na poziomie do $25 \%$ dla każdej grupy mineralogicznej. W strefie d podobnie jak w strefie b, przy jednocześnie stwierdzonej podatności na szczelinowanie, za sprawą wysokich udziałów kwarcu (około 38\%), stwierdza się wzbogacenie w materię organiczną na poziomie 2-3\% objętościowych. Ostatnia strefa (e) charakteryzuje się anomalnie wysoką podatnością z uwagi na przeważający udział minerałów kruchych, na poziomie około $70 \%$ i 12\% objętościowych minerałów węglanowych i kwarcu.

\section{Przestrzenna charakterystyka modułu Younga}

W ramach przestrzennej wizualizacji wyników estymacji modułu Younga opracowano model 3D tego parametru dla analizowanych poziomów macierzystych PM_I i PM_II. Z uwagi na silną relację pomiędzy danymi sejsmicznymi ( $V p)$ a otworowymi (moduł Younga - wyestymowane krzywe oparte m.in. na prędkości fali poprzecznej) wykonano transformację amplitudowego wolumenu sejsmicznego 3D do postaci reprezentującej przestrzenną dystrybucję modułu Younga z wykorzystaniem technik sieci neuronowych w procedurze inwersji genetycznej. Wykonano dwa modele tego parametru - 1) wykorzystując dane bazujące na wariancie I (referencyjnym) oraz 2) III", dla którego otrzymano najmniejszy błąd estymacji. Wykorzystując powstałe modele parametryczne, wygenerowano mapy średnich wartości analizowanego parametru oddzielnie dla poziomu macierzystego I (rys. 5a i b) oraz II (rys. 5c i d). Miąższość wyznaczonych na rysunku 4 stref o podwyższonej podatności na szczelinowanie nie przekracza kilku metrów (jest mniejsza aniżeli rozdzielczość danych 

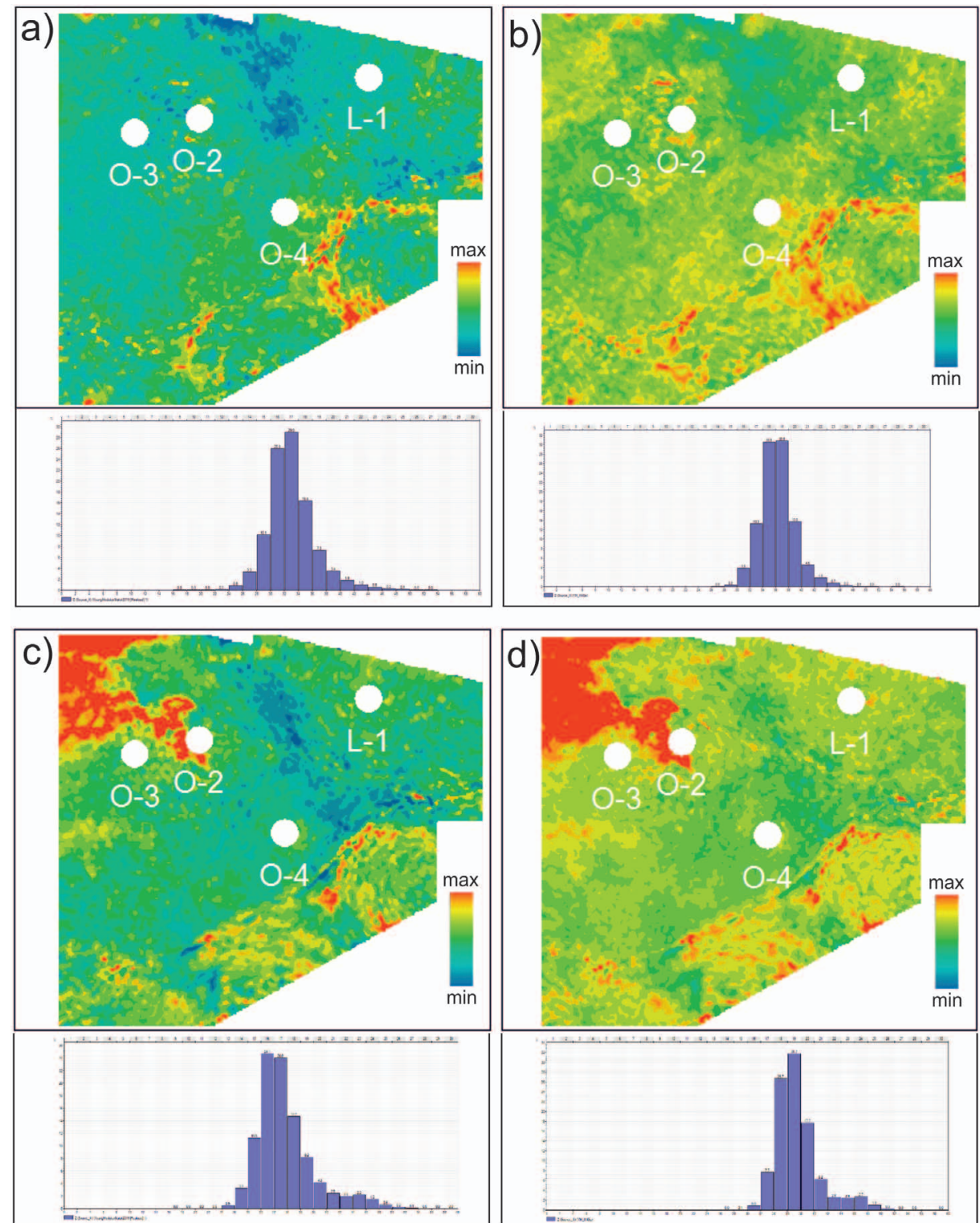

Rys. 5. Mapy średnich wartości modułu Younga w poziomie macierzystym PM_I w modelu opartym na danych w wariancie a) I i b) III" oraz w poziomie macierzystym PM_II analogicznie w wariancie c) I i d) III" wraz z histogramami dystrybucji wartości tego parametru

Fig. 5. Maps of average values of Young modulus within the PM_I source interval generated from a model created based on data in variant a) I, b) III" and within the PM_II source interval c) based on variant I and d) III"

sejsmicznych, na podstawie których powstał model przestrzenny), w związku z czym mapy średnich wartości modułu Younga przedstawiono $\mathrm{w}$ interwałach występowania analizowanych poziomów macierzystych. Kolorem czerwonym oznaczone są strefy charakteryzujące się średnio największą podatnością na szczelinowanie $\mathrm{w}$ danym interwale, natomiast niebieskim - najmniejszą.

\section{Podsumowanie}

W niniejszym artykule zaprezentowano kilka wariantów estymacji prędkości fali poprzecznej oraz sposób walidacji uzyskanych wyników, mając do dyspozycji rzeczywisty pomiar referencyjny tego parametru. Rezultaty estymacji analizowanego parametru w poszczególnych wariantach zostały wykorzystane do obliczenia dwóch parametrów sprężystych istotnych w kontekście geomechanicznej charakterystyki złóż - modułu Younga i współczynnika Poissona. Podwyższone wartości modułu Younga i niskie wartości współczynnika Poissona charakteryzują strefę o podwyższonej podatności na zniszczenia mechaniczne. Analiza w profilu wiertniczym parametrów sprężystych obliczonych przy wykorzystaniu różnych podejść wykazała analogiczne trendy wskazujące dokładnie te same strefy charakteryzujące się zbliżonymi między sobą wskazaniami, a tym samym podatnością na szczelinowanie. W badanym profilu łupków sylurskich w obrębie poziomu macierzystego I i ordowickich w obrębie PM_II wyznaczono łącznie osiem stref charakteryzujących się podniesioną podatnością na szczelinowanie hydrauliczne. Wśród tych stref znajdują się trzy szczególnie atrakcyjne z uwagi na jednoczesne wzbogacenie w materię organiczną na poziomie $4,9 \% \mathrm{w}$ strefie $\mathrm{B}$, do $6 \% \mathrm{w}$ strefie b i do $3 \%$ objętościowych w strefie d. Stwierdzone różnice w podatności na szczelinowanie hydrauliczne w obu poziomach macierzystych dają podstawę do zastosowania w każdym z nich odmiennego podejścia przy projektowaniu zabiegu szczelinowania.

Zważywszy na wykorzystanie prędkości fali podłużnej $(V p)$ i poprzecznej $(V s)$, bazujących na danych geofizyki otworowej do obliczeń parametrów sprężystych, przedstawione w niniejszym artykule parametry sprężyste mają charakter dynamiczny i mogą być zastosowane do jakościowej oceny analizowanych formacji. W celu przeprowadzenia dalszej analizy ilościowej konieczne będzie wykorzystanie statycznych odpowiedników obliczonych parametrów.

Istotną kwestią do rozważenia, nadającą kierunek kolejnemu etapowi prac związanych z omawianą tematyką, jest wpływ poszczególnych parametrów charakteryzujących szczeliny i szczelinowatość na prędkość fal podłużnych i poprzecznych 
oraz parametry sprężyste. Pozwoli to na ocenę, które parametry opisujące spękania (geometria sieci szczelin, geometria poszczególnych spękań, ich apertura i rodzaj wypełnienia) mają najistotniejszy wpływ na przebieg fal i identyfikację rodzaju ich wypełnienia (mineralizacja minerałami węglanowymi, kwarcem czy wypełnienie mediami złożowymi).

Artykuł powstał na podstawie pracy statutowej pt.: Relacje pomiędzy parametrami elastycznymi a petrofizycznymi $w$ kontekście charakterystyki przestrzennej wybranego złoża węglowodorów - praca INiG - PIB na zlecenie MNiSW; nr zlecenia: 0038/ SG/2019, nr archiwalny: DK-4100-0038/2019.

\section{Literatura}

Bała M., 2017a. Modelowanie własności sprężystych skał łupkowych z gazem z użyciem programu Estymacja. [W:] Jarzyna J., Wawrzyniak-Guz K. (red.). Adaptacja do warunków polskich metodologii wyznaczania sweet spotów na podstawie korelacji pomiarów geofizycznych z rdzeniami wiertniczymi. Monografia AGH, Kraków: 73-75. ISBN 978-837464-915-5.

Bała M., 2017b. Charakterystyka parametrów sprężystych określonych na podstawie pomiarów geofizyki otworowej i modelowań teoretycznych w wybranych formacjach w otworach basenu bałtyckiego i wierconych na szelfie. Nafta-Gaz, 8: 558-570. DOI: 10.18668/NG.2017.08.03.

Bjørlykke K., Høeg K., Haque Mondol M., 2010. Introduction to Geomechanics: Stress and Strain in Sedimentary Basins. [W:] Bjørlykke K. (ed.). Petroleum Geoscience: From sedimentary environments to rock physics. Springer, Heidelberg: 281-298. DOI: $10.1007 / 978-3-642-34132-8$

Bratton T., Cooper I., 2009. Wellbore Measurements: Tools, Techniques, and Interpretation. [W:] Aadnoy B., Cooper I., Miska S., Mitchell R., Payne M. (eds.). Advanced Drilling and Well Technology. Society of Petroleum Engineers: 443-457.

Castagna J.P., Batzle M.L., Eastwood R.L., 1985. Relationships between compressional-wave and shear-wave velocities in clastic silicate rocks. Geophysics, 50(4): 571-581. DOI: 10.1190/1.1441933.

Cyz M., Mulińska M., Pachytel R., Malinowski M., 2018. Brittleness prediction for the Lower Paleozoic shales in northern Poland. Interpretation, 6(3): 1-11. DOI: 10.1190/int-2017-0203.1.

Greenberg M.L., Castagna J.P., 1992. Shear-wave estimation in porous rocks: Theoretical formulation, preliminary verification and applications. Geophysical Prospecting, 40(2): 195-209.

Herwanger J., Koutsabeloulis N., 2011. Building Reservoir Geomechanical Model. [W:] Herwanger J., Koutsabeloulis N. Seismic Geomechanics: How to Build and Calibrate Geomechanical Models using 3D and 4D Seismic Data. EAGE Publications, Houten: 17-37.

Jędrzejowska-Tyczkowska H., Słota-Valim M., 2012. Mechaniczny model Ziemi jako nowy i konieczny warunek sukcesu w poszukiwaniach i eksploatacji niekonwencjonalnych złóż węglowodorów. Nafta-Gaz, 6: 329-340.
Kasza P., Kenar P., Pietka W., 2016. Specyfika udostępniania złóż niekonwencjonalnych w Polsce. Nafta-Gaz, 10: 799-804. DOI: 10.18668/NG.2016.10.04

Kwietniak A., Cichostępski K., Pietsch K., 2018, Resolution enhancement with relative amplitude preservation for unconventional targets. Interpretation, 6(3), SH59-SH71.

Poprawa P., 2009. Potential for Gas Shale Exploration in the Upper Ordovician-Silurian and Lower Carboniferous Source Rocks in Poland. AAPG Ann. Convent. \& Exhibit., 7-10.06.2009, Denver, Colorado, USA, Abstracts Volume.

Poprawa P., 2010. System węglowodorowy z gazem ziemnym w łupkach - północnoamerykańskie doświadczenia oraz europejskie perspektywy. Przeglad Geologiczny, 58: 216-225.

Poprawa P., Kiersnowski H., 2008. Perspektywy poszukiwań złóż gazu ziemnego w skałach ilastych (shale gas) oraz gazu ziemnego zamkniętego (tight gas) w Polsce. Biul. Państw. Inst. Geol., 429: 145-152.

Slatt R.M., 2011. Important geological properties of unconventional resource shales. Central European Journal of Geosciences, 3(4), 435-448. DOI: 10.2478/s13533-011-0042-2.

Słota-Valim M., 2014. Projektowanie wtórnego zabiegu udostępniania złóż typu niekonwencjonalnego z uwzględnieniem geomechanicznego modelu Ziemi. Nafta-Gaz, 9: 563-573.

Słota-Valim M., 2015. Static and dynamic elastic properties, the cause of the difference and conversion methods - case study. Nafta-Gaz, 11: 816-826. DOI: 10.18668/NG2015.11.02.

Sowiżdżał K., 2013. Geologiczne, przestrzenne modelowanie złóż węglowodorów - aspekty metodyczne i przykłady zastosowań. Prace Naukowe INiG - PIB, 192: 1-217.

Varacchi B., Jaiswal P., Puckette J., Dvorkin J., 2012. Elastic Properties of Silica Rich Mudrocks: Woodford Shale, Andarko Basin, Oklahoma. Society of Exploration Geophysicists. SEG-2012-1230.

Zoback M.D., 2010. Elastic moduli and seismic wave velocity. [W:] Zoback M.D., Reservoir Geomechanics. Cambridge University Press, Cambridge: 63-65.

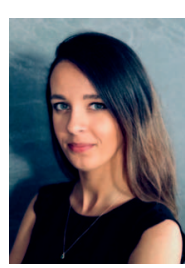

Mgr inż. Weronika KACZMARCZYK

Asystent w Zakładzie Geologii i Geochemii Instytut Nafty i Gazu - Państwowy Instytut Badawczy ul. Lubicz 25 A

31-503 Kraków

E-mail: weronika.kaczmarczyk@inig.pl

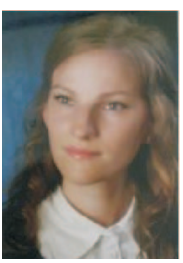

Dr inż. Małgorzata SŁOTA-VALIM

Asystent w Zakładzie Geologii i Geochemii, Laboratorium Petrofizyki

Instytut Nafty i Gazu - Państwowy Instytut Badawczy ul. Lubicz 25 A

31-503 Kraków

E-mail: slota@inig.pl 